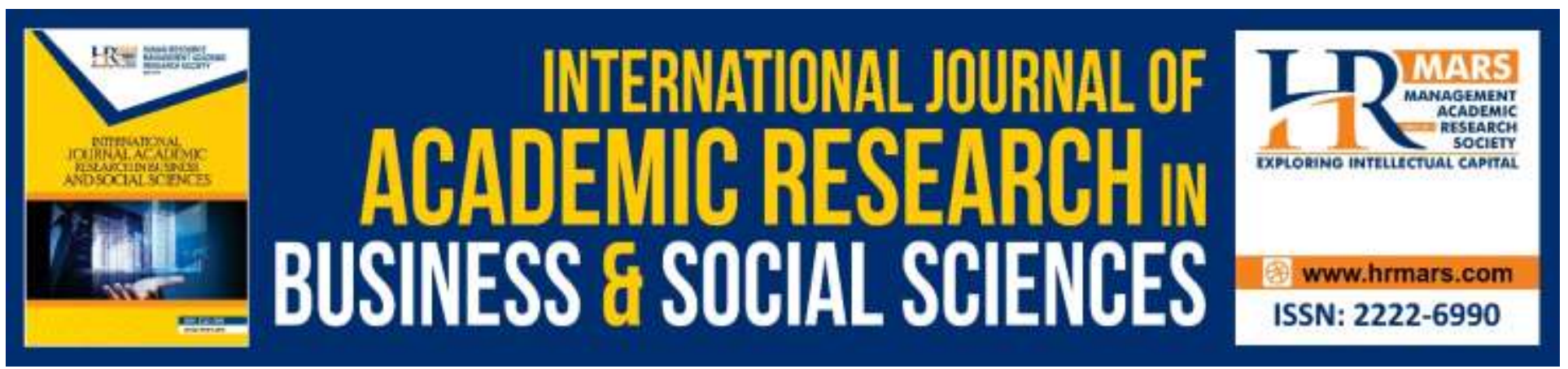

\title{
Gender Analysis Amongst Male and Female Malaysian Travelling Bloggers
}

\author{
Elaf Saad Bustan, Hussien Mohammed Alakrash
}

To Link this Article: http://dx.doi.org/10.6007/IJARBSS/v10-i6/7256

DOI:10.6007/IJARBSS/v10-i6/7256

Received: 14 March 2020, Revised: 22 April 2020, Accepted: 27 April 2020

Published Online: 02 June 2020

In-Text Citation: (Bustan \& Alakrash, 2020)

To Cite this Article: Bustan, E. S., \& Alakrash, H. M. (2020). Gender Analysis Amongst Male and Female Malaysian Travelling Bloggers. International Journal of Academic Research in Business and Social Sciences, 10(6), 1-9.

Copyright: (C) 2020 The Author(s)

Published by Human Resource Management Academic Research Society (www.hrmars.com)

This article is published under the Creative Commons Attribution (CC BY 4.0) license. Anyone may reproduce, distribute, translate and create derivative works of this article (for both commercial and non-commercial purposes), subject to full attribution to the original publication and authors. The full terms of this license may be seen

at: http://creativecommons.org/licences/by/4.0/legalcode

Vol. 10, No. 6, 2020, Pg. 1 - 9

http://hrmars.com/index.php/pages/detail/IJARBSS

JOURNAL HOMEPAGE

Full Terms \& Conditions of access and use can be found at http://hrmars.com/index.php/pages/detail/publication-ethics 


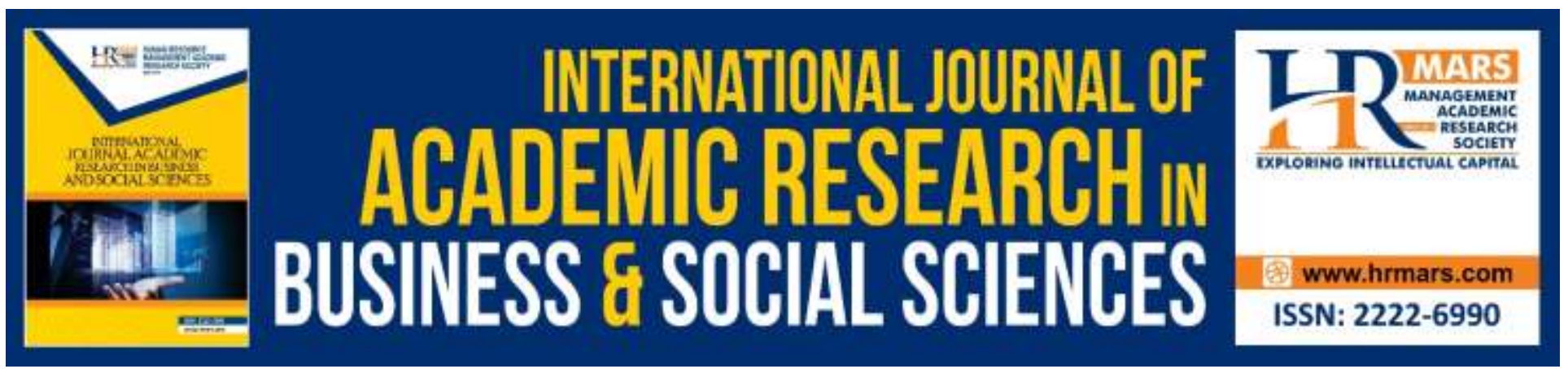

\title{
Gender Analysis Amongst Male and Female Malaysian Travelling Bloggers
}

\author{
Elaf Saad Bustan, Hussien Mohammed Alakrash \\ School of Language Studies and Linguistics, Faculty of Social Science and Humanities, Universiti \\ Kebangsaan Malaysia, Bangi, Selangor. \\ Email: elafsaad01@gmail.com, Hussienalakrash94@gmail.com
}

\begin{abstract}
Social media has been provided another means for young people to express themselves using language as a tool. This study aimed to examine the main differences between male and female traveling Malaysian bloggers in terms of descriptive writing and main vocabularies. the study adopted entirely a qualitative research design. the data of the study is analyzing in terms of content analysis as we are dealing with written text. Also, the sampling of the study is selected in the purposive and random selecting sample. the researcher utilized Lakoff"s theory (1974) in analyzing the data. The findings of the study have been manifested that there are differences between female and male traveling Malaysian bloggers. Malaysian female bloggers write up are more descriptive terms than male bloggers. yet, for the main vocabulary, both genders did not display any differences in the wording utilized.
\end{abstract}

Keywords: English Language Use, Gender, Blogs, Teenagers, Language Features.

\section{Introduction}

The difference between males and females in the way of use language is one of the most fundamental research subjects among the scientist during the last decades as a result of its importance in communication. So, scholars based on the differences between males' and females' speech and the way they use language. Furthermore, how to achieve effective communication. Haas (1979) it has been observed that male's and female's speech differ in their form, topic, content, and use. According to the past studies on this problem, believe that male may be more orientation and instructions as they use more non-standard forms, talk more about sports, money, and business, and more frequently refer to time, space, quantity, destructive action, perceptual attributes, physical movements, on the other side, females are often more supportive, polite, and expressive, talk more about home and family, fashion, how to prepare food...etc. and use more words implying feeling, evaluation, interpretation, and psychological state. There is a general agreement that females are more likely to use politeness models than males in their speech. Lakoff, one of the most expatiate insensitive in this issue, distinguishes females' speech from males speech in these striking features 
including the use of words related to their interests, empty adjectives, question intonation, hedges, hypercorrect grammar and super polite forms (Lakoff, 1975). According to society, they are pressed to speak like a lady. Therefore, it leads to females using more hedging and capacitors compared to males. Male and female use language in the light of community traditions on how to communicate. The most obvious differences between the use of language for males and females in their blog posts are lexical hedges. The results of this study seem to support Lakoff's (1975) theory that females use condensates more than males. This feature is related to gender, where female who seeks to hear tend to use capacitors to enhance language (Holmes, 2000). However, using this feature creates an impression that users are overpriced to describe something. The use of lexical hedges in the language of female bloggers reveals that they tend to write spontaneously while male bloggers tend to think before they write. The term gender is a very global concept both of these terms which are gender and sex are very difficult to separate. In Penelope Eckert and Sally McConnell, "s book Language and Gender the difference between gender and sex is demonstrated as "Sex is biological categorization based primarily on reproductive potential whereas gender is the social elaboration of biological sex" (Eckert\& McConnell-Ginet, 2013, Razak et al, 2018). That gender is an essential part of the world image and at the center of our social world can be seen already in how we raise our children and that blue is still considered a boy colour" and pink a "girl colour". However, even though there are biological features that distinguish us as female or male we tend to exaggerate our differences and instead of labelling us as just female or male we also label different behaviours feminine or masculine. Consequently, everything in society is now based on gender and even though people, in general, have reached higher awareness of gender equality there is still a long way to go to reach equal opportunities for both men and women.

\section{Problem Statement}

The differences between Males and females. According to Lakoff (1975), males and females are not only different biologically and psychologically. However, they are also different in the way they use language. Each has its vocabulary and method of expression. Although, they are speaking the same language but don't talk in similar contexts. For this reason, each party must be aware of the other's language and meaning to avoid many of the traumas resulting from misunderstanding. At first, you see that when a male speaks, he was chosen their words accurately and realistically. Every word they utter they mean it Eisenmen (1997) Therefore; we were seen a well-ordered, sequential, and logical language that avoids using the emotion in Hadith. While, when females are speaking uses emotion, lack of confidence in their voice, and tentativeness in the speech of females hasty in their judgments. He expresses her feeling that females always in their speech use empty adjectives, intensifiers and qualifiers, Tag questions, hedges, and polite forms. Females always hesitate in using the appropriate vocabulary in opposite males.

\section{Significance of the Study}

This study aims to look at the differences in speech between males and females. The focus of the study will be based on the linguistic features listed by Lakoff $(1973,1975)$ such as politeness, gender, and other features such as tag questions, hedging, and polite forms. This case of study investigates the differences in the speech of those 10 males and 10 females' bloggers. Also, to look at the specialist vocabulary on traveling (Michael et al, 2010). 
INTERNATIONAL JOURNAL OF ACADEMIC RESEARCH IN BUSINESS AND SOCIAL SCIENCES

Vol. 10, No. 6, June, 2020, E-ISSN: 2222-6990 @ 2020 HRMARS

\section{Research Objectives}

The objectives of the research

1. To identify the difference between males and females in terms of descriptive writing.

2. To explore the main vocabularies used by males and females in traveling.

\section{Theoretical Framework}

Since, a plethora of studies conducted in social dialect, syntactic, morphology, pronunciation, constructions as multiple negations such as style and semantic (Holmes, 2008). One of the studies conducted by Trudgill (1968) pointed out that in Norwich English males use more non-standard [n] forms than females. Labov (1966) in his study also stated that the people in New York city more people utilized post-vocalic $[r]$ they deemed are more prestigious, women pronounce the postvocalic [r] more than men. All the research that scrutinized the differences between men and woman speech emphasized on phonetic features rather than conversational strategies. This study is distinguished as it focuses on gender differences within the interlocutor's conversational styles, such as the function of the talk, conversational feedback, repetition, dominance in conversation solidarity, and phonological variations. Lakoff (1975) studies rasterize language as 1- Lexical hedges or fillers (you know, sort of, well, you see) 2- Tag questions (she's very nice, isn't she?) 3- Rising intonation on declarative (it's really good) 4- 'Empty' adjectives (divine, charming, cute) 5- Precise colour terms (magenta, aquamarine) 6- Intensifiers such as just and so (I like him so much) 7- 'Hypercorrect' grammar (consistent use of standard verb forms) 8- 'Super-polite' forms (indirect requests, euphemism) 9- Avoidance of strong swear words (fudge, my goodness) 10- Emphatic stress (it was a brilliant performance) Lakoff (1975) states language functions to express lack of confidence, uncertainty or tentativeness (Holmes, 2008; Razak et al, 2018). Lakoff (1975) argued that the use of hedging devices by women signal evidence of their uncertainty, and boosting devices express their anticipations that the addressee may still unconvinced, so they need to supply another evidence and analysing data were artificial as she collected her data in a laboratory with a screen between the speakers. The results also were contradictory, because many sociolinguists noted that men used more tag questions than women did, and some others found that there were no gender differences (Holmes, 2008). Based on different sociolinguistics studies, which carried on investigating the differences between men's and women's language, most sociolinguists have agreed that women used more standard forms than men who tend to use vernaculars. As per to Holmes (2008), there are different reasons why women use more standard forms. First, the social norms of a society that we expect women's behavior as a model, this will affect the language they use. Also, women are more status-cautious rather than men. Women are alleged by a stereotypical expectation when they speak, whatever they say "can be used against them as evidence of their deficiencies"(Holmes, 1985). Women also lack status in the society, so they "try to acquire it by using standard speech forms, and by reporting that they use even more of these forms than they do" (Holmes, 2008).

\section{Literature Review}

In this study Amir et al (2012). explored the differences in language use by male and lady Malaysian teenager's bloggers who utilized blogs as a rag to express their problems or affairs in their daily life. This study goal was to investigate gender differences noticed in the language utilized by male and lady teenager's bloggers in their blogs. The final result found that there are distinguishes among male and lady bloggers in the recurrence of five languages which are tag question, hedging, empty 
adjectives, and intensifiers .the current study will be emphasizes on 20 Malaysian adult bloggers to show at first, the differences between male and lady in idioms of descriptive writing. Furthermore, what are the main vocabularies that were used by both males and females through traveling.

Gong (2010) in his study he examines for the same age, gender to both American and Chinese bloggers. In these blogs the bloggers whether Americans or Chinese bloggers tries to clarify them linguistically and culturally through their blogs. However, the study investigates how far these two groups of bloggers different from each other's. According to language the use and their cultures. The approach that is depended in this study from the side of the writer is corpus - based approach. Also, emphasizes on the description. While, the present study will be focuses on 20 Malaysian adult bloggers to show at first, the differences between male and lady in idioms of descriptive writing. Furthermore, what are the main vocabularies that were used by both males and females through travelling. And, the theory that is the researchers adopted in this current study is lakoff gender theory (1975). The study by Akhter (2014) stated that the majority of the girls are using formal language, hedging, empty adjectives, raising tones, syntactic style, intensifiers, and ...etc on the other side the boys are the vis versa of the girls. the study of Akhter has been conducted on the Bangladesh students. According to Huffaker (2004) in his study examined the differences and similarities between teenager's bloggers, the researcher emphasizes on significant characteristics of an online organization like first i. their names, age, gender, marriage, or not, their school and interesting( demographic information). Eckert (1998); Holmes (2008) avert that women's language is more conservative than men's because women are more status-conscious or polite and men are tough. finally, Trudgill (1972) in his study adopted that women are more conservative in using almost variables of pronunciation in Norwich, because women are excluded from the workplace, and because they have fewer opportunities to secure their positions by being successful at work or other abilities; they find it essential to use the standard forms to enhance their positions.

\section{Methodology \\ Research Design}

Using a qualitative research design. Findings from this study can be used to generalize to the population the sample is taken from even though it is a small sample. In other words, data from a group of people will be qualitatively analysed for in-depth interpretations. This is supported by Merriam (2009) who states that a case study is restricted by time and activities and the data will be collected using a variety of methods over a continued period of time. This study will investigate language use among male and female teenagers who created and maintained their blogs over a period of three months. The blogs were chosen from BlogMalaysia.com and the URL is www.blogmalaysia.com. BlogMalaysia was chosen because it is free and is the fastest growing blog directory in Malaysia. This website has a list of blog links in

\section{Data Sampling}

The main participants for this study were selected from BlogMalaysia.com., a platform in Malaysian Bloggers Directory. BlogMalaysia.com is open to any Malaysian blogger who wants to promote his/her blog and to discover new blogs operated by other Malaysian bloggers. Since the focus of this study was to observe any gender differences in language use by Malaysian teenagers who frequently update their blogs, following Azni (2008), the following types of blogs found in BlogMalaysia.com 
INTERNATIONAL JOURNAL OF ACADEMIC RESEARCH IN BUSINESS AND SOCIAL SCIENCES

Vol. 10, No. 6, June, 2020, E-ISSN: 2222-6990 @ 2020 HRMARS

were excluded from this study: i. Blogs with multiple authors; ii. Blogs with pictures only and; iii. Blogs which are only for commercial and organizational purposes.

\section{Research Instrument}

The data for this study is from the blog postings of the four teenagers who treat their blogs as a diary where they express their feelings about daily issues to do with their lives and their studies. The instruments of analysis were a word counting tool and a checklist. The following is a description of the data sources and the instruments:

\section{Data Analysis}

The data analysis method for this study is content analysis, Lakoff's theory will be used to analyse tha language to see how women's language is different and distinguished from men. Besides, the posts will also be analyzed in terms of traveling related terms.

\section{Findings and Results}

Frockmeimfamous.com vs wanderingtrader.com

This subunit will be discussing on posting from two bloggers; Hayley from frockmeimfamous.com and Jeffrey Hagenmeier from wanderingtrader.com. From frockmeimfamous.com the posting that was chosen is The ULTIMATE Guide to Singapore: How to Spend 3 Days in Singapore and from wanderingtrader.com the article chosen is Darvaza Gas Crater: The Door to Hell in The Karakum Desert of Turkmenistan.

In the posting of The ULTIMATE Guide to Singapore: How to Spend 3 Days in Singapore, the blogger uses expressive words such as adore and love. Upon further analysis, the blogger also using the firstperson point of view, and her wordings are used in such to depict her excitement towards the place she was visiting. For example, she wrote, "I'm so glad that I've explored Little India as it's by far my favorite neighborhood in Singapore and one that l'd recommend exploring!" From this example, it is visible how expressive a female style of writing can be. As per Lakoff's gender framework, the female tends to be more descriptive in their writing, thus the blogger does write descriptively when she is depicting Haji Lane in Singapore. She wrote "...-packed full of colorful streets and wonderful street arts; a must-visit". The blogger also adhering to one of Lakoff's gender framework theories that are females tend to be more polite in their speech or writing.

Looking into wandering trader .com's posting of Darvaza Gas Crater: The Door To Hell in The Karakum Desert of Turkmenistan, the blogger is using rather straight forward sentences as it directly tells the history of the place, "Unwittingly, they instead created, one of the most unique tourist destinations in the world." As per the sentence, the blogger used a rather direct and straight forward adjective to depict Darvaza Gas Crater. Cross-checking it with Lakoff's framework, the male writing style is more direct and less expressive compared to females. In his writing, the blogger in depicting the surrounding environment, he only used 'can be quite beautiful' to retell the landscape with the Darvaza Gas Crater.

Thus when comparing the two bloggers, the results are that the female blogger wrote in more descriptive and politeness while the male blogger wrote in rather direct and provided sufficient details of the trips to his reader. Also, the female blogger's posting feels more intimate comparing to the male blogger, as she uses her sentences to express her emotions during her traveling period. Furthermore, looking into the traveling terms used by both bloggers, it comes to notice that female 
INTERNATIONAL JOURNAL OF ACADEMIC RESEARCH IN BUSINESS AND SOCIAL SCIENCES

Vol. 10, No. 6, June, 2020, E-ISSN: 2222-6990 @ 2020 HRMARS

bloggers stills use the expressive adjective in using the terms such as "...offering a Premium service at a not-so-premium price tag!" in referring to her in-flight experiences.

Twinsthattravel.com vs budgettraveller.org

This subunit will discuss "autumn in Provence" by twinsthattravel.com and "Where the Wild Horses Roam in Latvia" by.com.

Using Lakoff's criteria of female writing, it is found that in Autumn in Provence, the female bloggers used descriptive as well as an expressive adjective to picturesque the scenery of the day. Laura from twinsthattravel.com used "...- overlooked the main square; golden leaves falling over café tables and chairs." By using the term golden leaves, she expressively depicting the autumn season that is taking budget traveller place at the time of visits. Another example of female descriptive writing style is when she depicted the moment of sun setting with "...just as the sun slipped below..." and used "...the green banks of the River Rhône." to describe the river bank. This blogger bringing her experience closer to the reader by using descriptive adjectives. In telling the story of the village, the blogger used "Cast in a balmy golden light, the village streets empty and residents resume their local-based traditions..." to illustrate the hue of autumn with the architectural design of the village.

In his visit to Jelgava, Latvia, Kashyap Bhattacharya took note of his journey including the time taken for him to move from place to place. For example in describing the café he visited, he took note and describes the journey to the café using time - "...in the 30 minutes we are there..." In his posting, Kash also used adjectives to describe the situation, such as in describing the café he went to, the blogger used "...to discover a brightly lit cafe, strong with the smell of caffeine and freshly baked goods." However, afterward, in retelling his experience, he wrote rather straightforwardly without using many descriptive adjectives to illustrate the condition such as in describing the wild horse he saw in his tour, "...small posse of about 10 wild horses grazing..." He only described the horses as wild but did not describe it descriptively. When comparing these two bloggers, the male blogger does not adhere to a much too general male style of writing. He used descriptive adjectives in his writing although much less than the female bloggers. However, when comparing side by side, female bloggers write up are more descriptive as Lakoff's theory. In terms of traveling jargons used, both genders did not display any differences in the wording used. However, the female bloggers give additional details on where to book airline tickets and the prices expected, whilst the male blogger only stressed out on the time taken for him to get to Jelvaga, Latvia.

\section{Conclusion}

The results of this study revealed that females bloggers wrote in more descriptive and politeness while the males bloggers wrote in rather direct and provided sufficient details of the trips to his reader. Also, the female blogger's posting feels more intimate comparing to the male blogger, as she uses her sentences to express her emotions during her traveling period. Furthermore, looking into the traveling terms used by both bloggers, it comes to notice that female bloggers stills use the expressive adjective in using the terms. The findings showed that there are differences between male and female bloggers in the frequencies of five language features which are 'intensifiers', 'hedging', 'tag questions', 'empty adjectives' and 'adverbs". The results of the study show that differences in language use among teenage bloggers may largely be attributed to gender.

The study contributes to the body of knowledge related to gender and the theory of gender and the understanding and practices surrounding the nature of speech between males and females. The current study will add to existing research and literature in the area of gender and sociolinguistic. 
INTERNATIONAL JOURNAL OF ACADEMIC RESEARCH IN BUSINESS AND SOCIAL SCIENCES

Vol. 10, No. 6, June, 2020, E-ISSN: 2222-6990 @ 2020 HRMARS

This study was limited to investigate the gender differenced in traveling bloggers, Future studies can investigate the gender differences

\section{References}

Akhter, I. (2014). Differences in language use by male and female students in tertiary academia in Dhaka city (Doctoral dissertation, BRAC University).

Akhter, I. (2014). Differences in language use by male and female students in tertiary academia in Dhaka city (Doctoral dissertation, BRAC University).

Amir, Z., Abidin, H., Darus, S., \& Ismail, K. (2012). Gender differences in the language use of Malaysian teen bloggers. GEMA Online ${ }^{\circledR}$ Journal of Language Studies, 12(1).

Archer, J., \& Lloyd, B. (2002). Sex and gender. Cambridge University Press.Archer, J., \& Lloyd, B. (2002). Sex and gender. Cambridge University Press.

Bamberg, M., \& Cooper, I. H. (2011). Narrative analysis. APA handbook of research methods in psychology (Vol. 3). Bamberg, M. 2012. Narrative Analysis. APA handbook of research methods in psychology 2(77-94).

Bhattacharya, K. (2018, November 22). Where the Wild Horses roam in Latvia. Retrieved from Budget Traveller: https://budgettraveller.org/things-to-do-jelgava-latvia/

Cooper, H. E., Camic, P. M., Long, D. L., Panter, A. T., Rindskopf, D. E., \& Sher, K. J. (2012). APA handbook of research methods in psychology, Vol 1: Foundations, planning, measures, and psychometrics. American Psychological Association.

Eckert, P., \& McConnell-Ginet, S. (2013). Language and gender. Cambridge University Press.

Eisenmann, B. (1997). Gender differences in early mother-child interactions: Talking about an imminent event. Discourse Processes, 24(2-3), 309-335.

Gong, W. (2010). Self and Identity in Personal Blogs: A Cross-linguistic and Cross-cultural Perspective. In Interpersonal Relations and Social Patterns in Communication Technologies: Discourse Norms, Language Structures and Cultural Variables (pp. 162-184). IGI Global.

Haas, A. (1979). Male and female spoken language differences: Stereotypes and evidence. Psychological Bulletin, 86, 616-626.

Holmes, J. (2000). Politeness, power and provocation: How humour functions in the workplace. Discourse studies, 2(2), 159-185.

Holmes, J., \& Meyerhoff, M. (2008). The handbook of language and gender (Vol. 25). Hoboken, NJ: Wiley.

Holmes, J., \& Meyerhoff, M. (Eds.). (2008). The handbook of language and gender (Vol. 25). John Wiley \& Sons.

Huang, W. J. (2015). A corpus-driven analysis of male and female weblog users in an ESL context/Huang Wen Jie (Doctoral dissertation, University of Malaya).

Huffaker, D. (2004). Gender similarities and differences in online identity and language use among teenage bloggers (Doctoral dissertation, Georgetown University).

Lakoff, G. (1975). Hedges: A study in meaning criteria and the logic of fuzzy concepts. In Contemporary research in philosophical logic and linguistic semantics (pp. 221-271). Springer, Dordrecht.

Lakoff, R. (1973). Language and Woman's Place. 2(1), 45-80. Retrieved from http://www.jstor.org/stable/4166707. 
INTERNATIONAL JOURNAL OF ACADEMIC RESEARCH IN BUSINESS AND SOCIAL SCIENCES

Vol. 10, No. 6, June, 2020, E-ISSN: 2222-6990 @ 2020 HRMARS

Lakoff, R. (2004). Language and Woman's Place: Text and Commentaries. USA, OxfordUniversity Press, 3.

Nemati, A., \& Bayer, J. M. (2007). Gender differences in the use of linguistic forms in the speech of men and women: A comparative study of Persian and English. Language in India, 7(9), 1-16.

Pedersen, S., \& Macafee, C. (2007). Gender differences in British blogging. Journal of ComputerMediated Communication, 12(4), 1472-1492.

Razak, N. A., Alakrash, H., \& Sahboun, Y. (2018). English Language Teachers' readiness For the Application of Technology Towards Fourth Industrial Revolution Demands. Asia-Pacific Journal of Information Technology and Multimedia, 7(2-2), 89-98.

Spence, J. T. (1985). Gender Identity and Its Implications for the Concepts of Masculinity and Femininity Janet T. Spence. Psychology and gender, 32, 59.

Subrahmanyam, K., \& Smahel, D. (2010). Digital youth: The role of media in development. Springer Science \& Business Media.

Trudgill, P. (1972). Sex, covert prestige and linguistic change in the urban British English of Norwich. Language in society, 1(2), 179-195

Zain, A. M., \& Koo, Y. L. (2016). Weblogging as a multimedia literacy event: Analyzing the discourse space of a student blogger's Speech Community. Malaysian Journal of ELT Research, 5(1), 26. 